\title{
IMPLEMENTASI CMS WORDPRESS PADA JOGJA MOTOR SPORTS BERBASIS E-COMMERCE
}

\author{
Billy Adam Sutrisno ${ }^{1)}$, Bima Cahya Putra ${ }^{2)}$ \\ ${ }^{1}$ Sistem Informasi, Fakultas Teknologi Informasi, Universitas Budi Luhur \\ ${ }^{1,2} \mathrm{Jl}$. Raya Ciledug, Petukangan Utara, Kebayoran Lama, Jakarta Selatan 12260 \\ E-mail : billyadam1018@gmail.com ${ }^{11}$, bimo.cahyoputro@budiluhur.ac.id ${ }^{2)}$
}

\begin{abstract}
Abstrak
Toko spareparts Jogja Motor Sports merupakan suatu usaha jenis wirausaha kecil dan menengah yang bergerak dalam bidang penjualan penjualan spareparts kendaraan roda dua. Masalah-masalah yang dihadapi oleh toko jogja motor sports adalah selama ini pelanggan tidak mengetahui adanya spareparts-spareparts yang terjual dengan adanya promo, pelanggan hanya bisa belanja dengan datang ke toko dan pelanggan yang datang hanya berasal dari sekitar saja, jadi penjualan spareparts dirasakan kurang meningkat, sering terjadi ketidakakuratan data pada proses pembuatan laporan, media promosi masih menggunakan iklan dimajalah otomotif sehingga dirasakan masih kurang dalam segi pemasarannya. Dengan adanya rancangan e-commerce yang menggunakan metode business model canvas, untuk meningkatkan penjualan sparepart pada toko jogja motor sports di tangerang guna mengembangkan penjualan barangnya tidak hanya secara offline saja, sehingga penjualannya dapat meningkat.
\end{abstract}

Kata kunci: Business Model Canvas, E-Commerce, Spareparts, CMS, Wordpress.

\section{PENDAHULUAN}

1.1. Latar Belakang

Perkembangan kebutuhan informasi sejalan dengan perkembangan ilmu pengetahuan dan teknologi yang semakin pesat, khususnya pada komputer dan internet. Dalam hal ini, komputer dan internet memegang peranan yang sangat penting sebagai alat bantu utama dalam pengelolaan data dan mencari informasi yang dibutuhkan. Teknologi internet saat ini digunakan tidak hanya untuk jejaring sosial tetapi juga digunakan untuk bisnis online. Salah satu penggunaan bisnis online saat ini dikenal dengan sebutan e-commerce.

Toko spareparts Jogja Motor Sports merupakan suatu usaha jenis wirausaha kecil dan menengah yang bergerak dalam bidang penjualan spareparts kendaraan roda dua. Media promosinya masih menggunakan iklan dimajalah otomotif sehingga memakai biaya yang tidak sedikit. Cara tersebut disaat ini kurang efektif dan kurang menggunakan teknologi yang ada.

Masalah yang dihadapi oleh toko Jogja Motor Sports adalah data yang selama ini pelanggan tidak mengetahui adanya spareparts-spareparts yang terjual dengan adanya promo, pelanggan hanya bisa belanja dengan datang ke toko dan pelanggan yang datang hanya berasal dari sekitar toko saja, jadi penjualan spareparts dirasakan kurang meningkat, sering terjadi ketidak-akuratan data pada proses pembuatan laporan, media promosi masih menggunakan iklan dimajalah otomotif sehingga dirasakan masih kurang dalam segi pemasarannya.

Penelitian ini bertujuan untuk mempermudah dalam penyajian informasi penjualan spareparts secara akurat dan tidak memerlukan waktu yang banyak, memudahkan dalam melakukan pemesanan barang dan dapat diakses dimana saja baik pihak Jogja Motor Sports maupun pelanggan, membuat laporan stok barang untuk mempermudah staff mengetahui informasi sisa stok barang tersebut. Business Model Canvas adalah suatu bisnis model gambaran yang logis mengenai suatu organisasi dapat menciptakan dan menangkap suatu nilai[1].

\subsection{Penelitian Sebelumnya}

a. Teori Penjualan

Penjualan adalah aktivitas yang terjadi antara penjual dan pembeli, penjual menawarkan barang atau jasa sehingga diharapkan mendapatkan untung dari suatu penjualan tersebut [2].

b. E-Commerce

Sebuah proses jual dan beli barang secara online oleh pelanggan dan dari perusahaan ke perusahaan dengan menggunakan komputer dan internet sebagai alat perantara transaksi suatu bisnis [3].

\section{c. Business Model Canvas}

Analisis BMC merupakan model bisnis yang berisi pemikiran dari sebuah organisasi menciptakan suatu nilai dalam organisasi tersebut .

\section{METODE PENELITIAN}

Dalam melakukan penelitian ini penulis menggunakan metode penelitian sebagai berikut : 


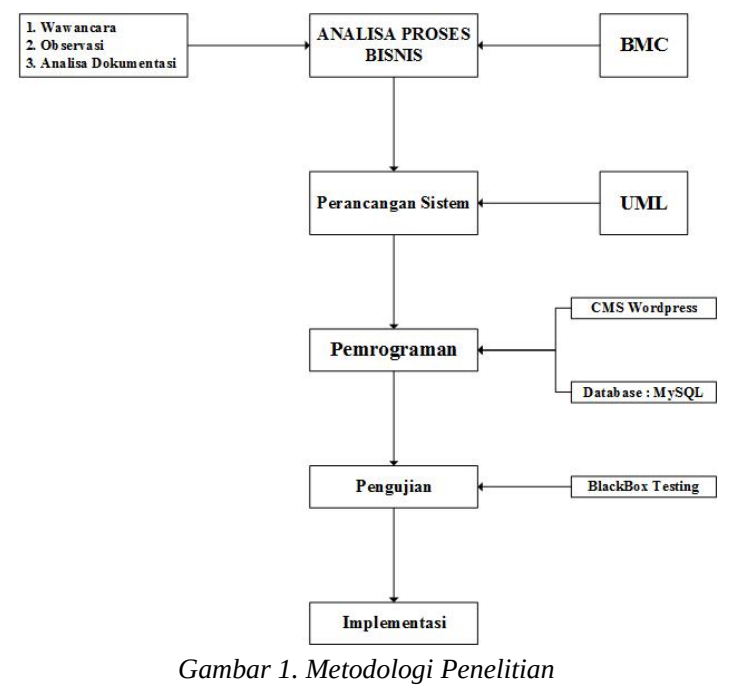

\subsection{Analisa Proses Bisnis}

Dalam penelitian ini, penulis meneliti proses bisnis sistem berjalan dengan cara-cara sebagai berikut :

1. Observasi, penulis mengumpulkan dan mengamati data-data yang ada secara langsung dari tempat riset untuk mengetahui proses bisnis sistem berjalan saat ini untuk memperoleh data secara jelas, lengkap dan akurat.

2. Wawancara, penulis mengajukan berbagai pertanyaan yang ditujukan kepada pemilik toko untuk mengetahui informasi mengenai permasalahan yang dihadapi oleh toko dan pelanggan.

3. Dokumentasi, penulis mengumpulkan dokumen-dokumen dari toko spareparts Jogja Motor Sports yang berhubungan dengan objek penelitian ini, seperti data barang, data transaksi serta data yang berasal dari supplier.

\subsection{Perancangan Sistem}

Dalam tahapan perancangan sistem ini penulis akan merancang sistem dengan membuat UML seperti Activity Diagram, Use Case, Class Diagram, Sequence Diagram.

\subsection{Pemrograman}

Dalam tahapan pemrograman ini penulis membuat website dengan CMS(Content Management System) Wordpress dan menggunakan database phpMyAdmin.

\subsection{Pengujian}

Setelah website sudah dibuat, penulis melakukan pengujian dengan teknik Black Box Testing. Dengan menggunakan black box testing guna mengetahui fungsi dari website dan melihat hasil yang dikeluarkan oleh website tersebut.

\subsection{Implementasi}

Setelah program dilakukan berbagai testing untuk memastikan bahwa website tersebut berjalan optimal maka selanjutnya penulis menerapkan website yang sudah dibuat dan sudah diuji tersebut kepada toko Jogja Motor Sports

\section{HASIL DAN PEMBAHASAN}

\subsection{Business Model Canvas}

Berikut ini adalah hasil Business Model Canvas yang telah penulis buat sebagai berikut :

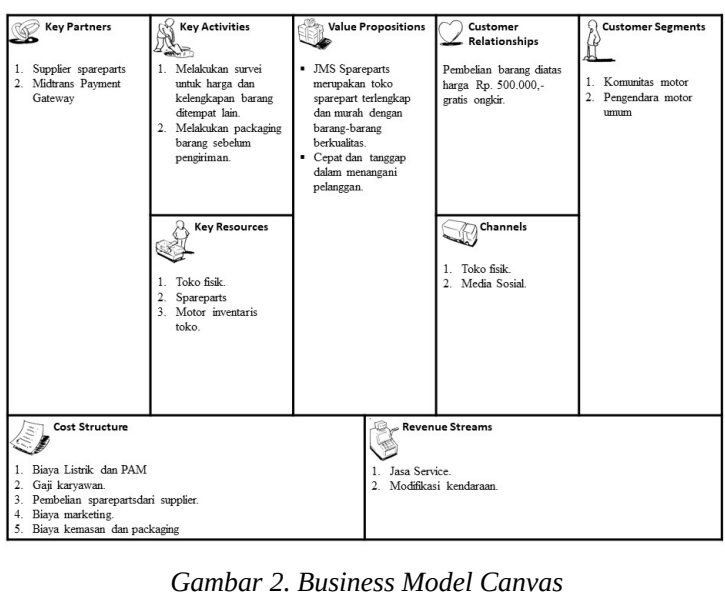

Dibawah ini adalah penjelasan tentang Business Model Canvas yang telah di buat :

a. Value Propositions

Bagian ini berisi tentang nilai tambah atau keunikan yang dimiliki oleh bisnis yaitu dengan menjual spareparts termurah dan berkualitas, serta memberikan pelayanan cepat dan tanggap kepada pelanggan.

b. Customer Segments

Bagian ini menjelaskan siapa pelanggan yang potensial dari produk yang telah dijual, seperti komunitas-komunitas motor dan pengendara motor biasa.

c. Revenue Streams

Bagian ini menjelaskan tentang keuntungan yang didapat dari pelayanan jasa service dan modifikasi kendaraan.

d. Key Activities

Bagian ini menjelaskan tentang kegiatan pemasangan spareparts secara langsung dan modifikasi kendaraan.

e. Key Resources

Bagian ini menjelaskan tentang sumber daya utama atau asset yang dimiliki oleh bisnis ini adalah toko fisik, spareparts, motor inventaris toko. 
f. Customer Relationships

Bagian ini menjelaskan bagaimana cara bisnis ini dapat keep in touch dengan para pelanggannya dengan cara mengadakan promo secara berkala.

g. Channels

Bagian ini berisi media yang bisnis ini gunakan untuk memberikan informasi toko kepada pelanggan melalui media sosial.

h. Key Partnerships

Bagian ini berisi tentang mitra-mitra yang berhubungan dalam bisnis ini seperti suppliers spareparts dan midtrans payment gateway.

i. Cost Structure

Bagian ini menjelaskan tentang biaya-biaya apa saja yang dikeluarkan seperti biaya listrik dan PAM, gaji mekanik, pembelian spareparts dari suppliers, biaya marketing dan biaya packaging.

\subsection{Activity Diagram Sistem Usulan}

Activity diagram adalah cara untuk menjelaskan tahapan-tahapan logika pada proses bisnis atau alur kerja yang terdapat pada penelitian ini [4]. Dibawah ini merupakan activity diagram yang penulis buat :

\section{1) Proses Pendaftaran Akun}

Pada proses pendaftaran akun, calon pelanggan harus mengisi data diri pada form registrasi. Selanjutnya sistem akan mengecek data kedalam database, jika pelanggan sudah memiliki akun maka pelanggan dapat langsung melakukan proses login.

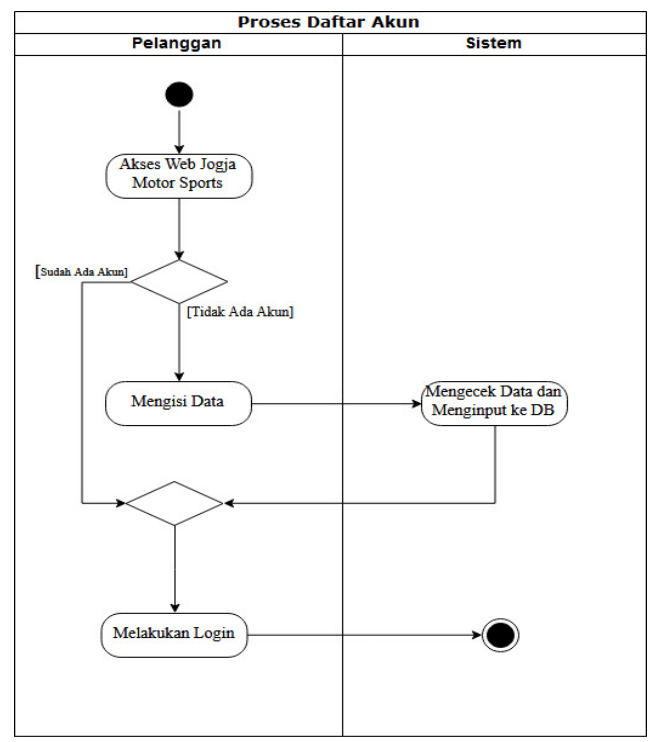

Gambar 3. Activity Diagram Proses Login

2) Proses Pemesanan Barang

Pelanggan harus login terlebih dahulu, kemudian memilih kategori dan barang yang diinginkan, lalu pelanggan memilih jenis barang dan jumlah barang dan selanjutnya dimasukan ke keranjang belanja. Jika melanjutkan barang yang sudah masuk ke dalam keranjang belanja, pelanggan memilih checkout. Selanjutnya pelanggan memilih orders dan sistem akan menyimpan data pemesanannya.

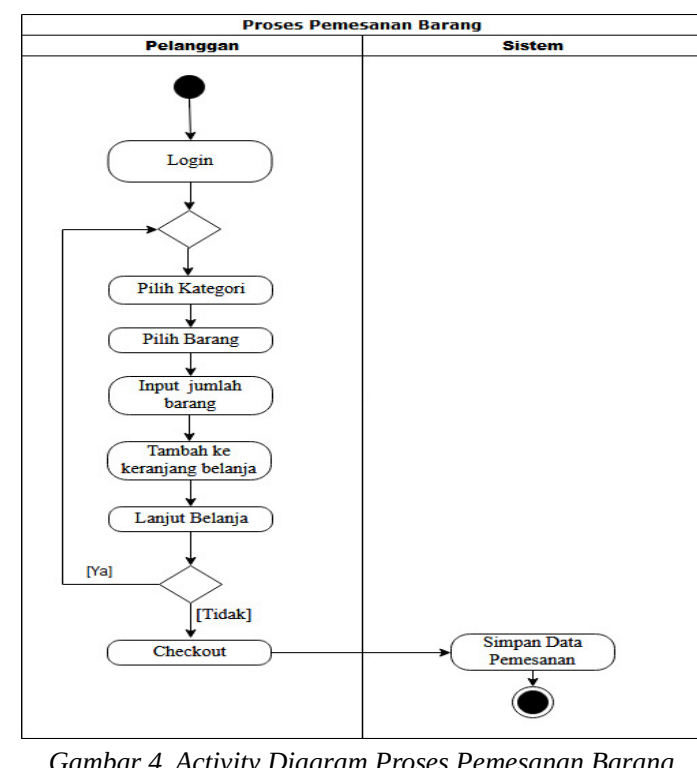

3) Proses Konfirmasi Pembayaran

Pelanggan memilih bank tujuan, kemudian melakukan transfer pembayaran. Setelah pelanggan melakukan transfer pembayaran, sistem akan mengkonfirmasi pembayaran dan mengubah status pembayarannya. Lalu sistem menyimpan data pembayaran kedalam database.

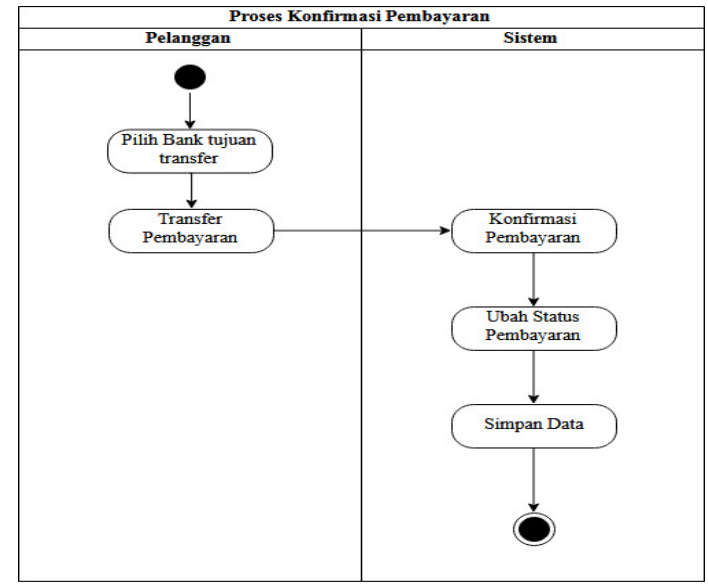

Gambar 5. Activity Diagram Proses Konfirmasi Pembayaran

4) Proses Laporan

Staff mengakses website dan melakukan login terlebih dahulu, kemudian staff memilih menu laporan dan mencetak laporan-laporan yang akan diberikan kepada pemilik sebagai laporan. 


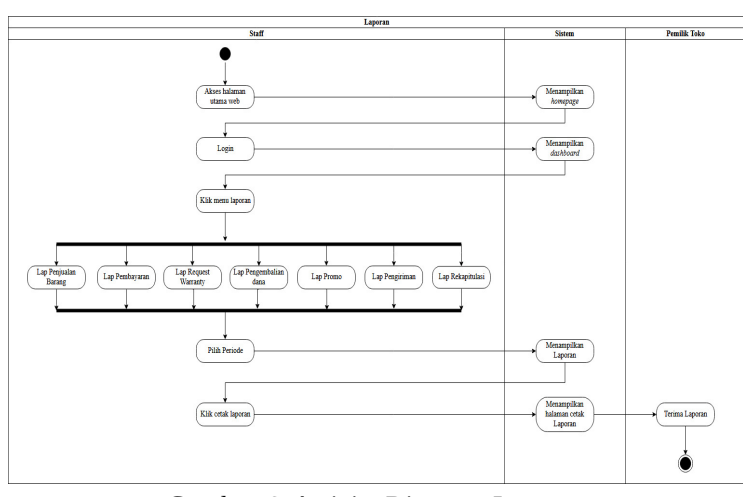

Gambar 6. Activity Diagram Laporan

\subsection{Use Case Diagram}

Usecase diagram merupakan serangkaian tindakan yang telah dilakukan oleh sistem, aktor melakukan berbagai interaksi atau aktivitas pada sebuah sistem yang dimodelkan [4].

a. Use case diagram master

Diagram Use Case Master pada Gambar 7 berisi aktivitas staff yang melakukan berbagai macam proses seperti entry data staff, entry data promo, entry data barang, entry data kategori barang.

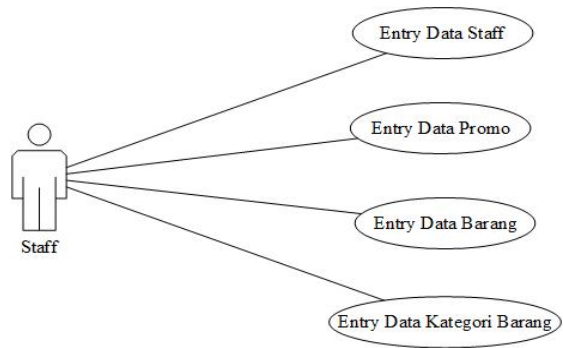

Gambar 7. Use Case Diagram Master

b. Use Case Transaksi

Use Case Diagram Transaksi pada Gambar 11 berisi aktivitas pelanggan dan staff dalam melakukan sebuah transaksi pada sistem.
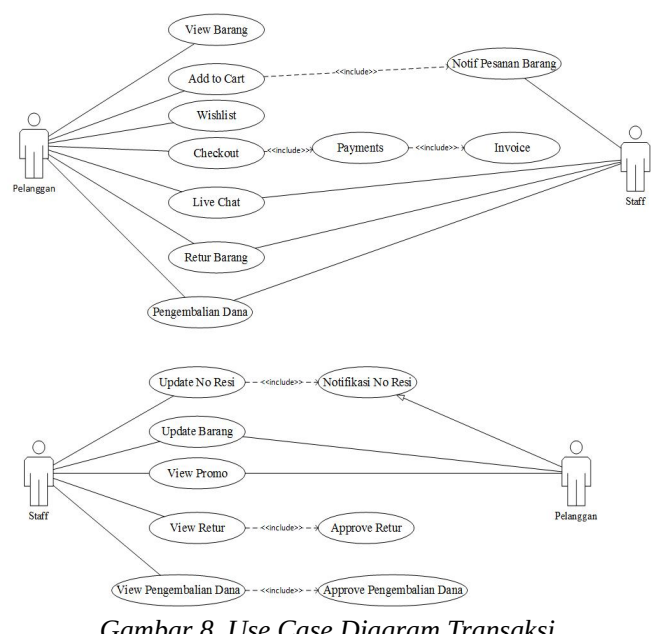

Gambar 8. Use Case Diagram Transaksi c. Use Case Laporan

Use Case Diagram Laporan pada Gambar 9 berisi laporan-laporan yang dikeluarkan oleh sistem untuk dicetak oleh staff dan dicek oleh pemilik toko.

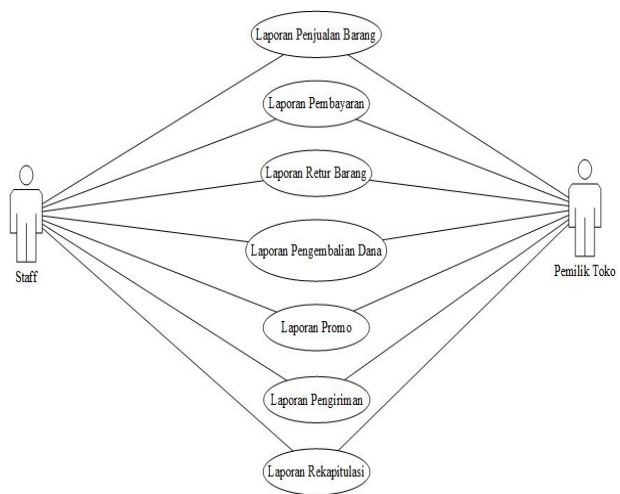

Gambar 9. Use Case Diagram Laporan

\subsection{Class Diagram}

Class diagram merupakan gambaran struktur sebuah sistem dalam mendefinisikan kelas-kelas yang akan dibuat dalam membangun sebuah sistem [5]. Class Diagram pada Gambar 10 menjelaskan relasi antar tabel yang berada di database website jogja motor sports.

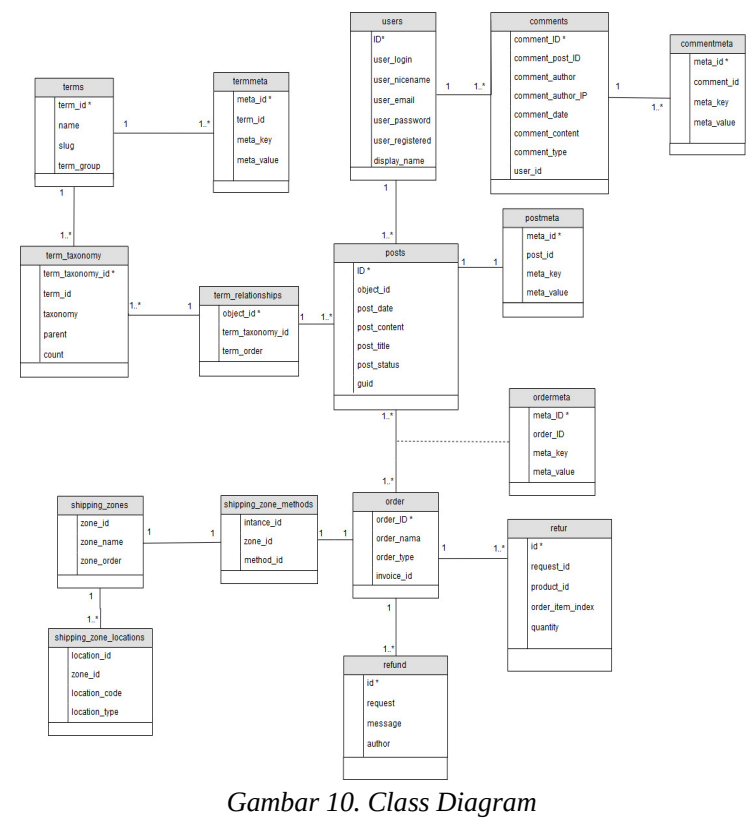

\subsection{Struktur Tampillan Menu}

Struktur tampilan menu adalah gambaran secara umum bentuk dari program atau sistem yang penulis buat [6]. Struktur tampilan menu yang telah penulis buat digambarkan dalam Gambar 11 dan Gambar 12. 
a. Frontend

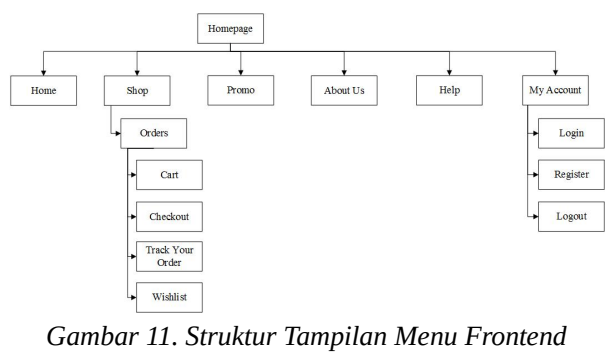

b. Backend

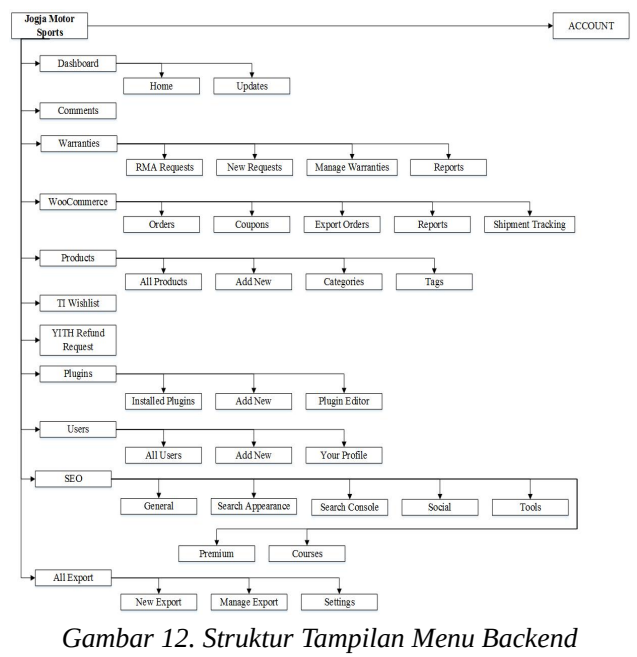

\subsection{Rancangan Layar}

a. Pendaftaran Akun

Form pendaftaran akun pada Gambar 13 adalah form untuk melakukan proses entry data staff atau data pelanggan.

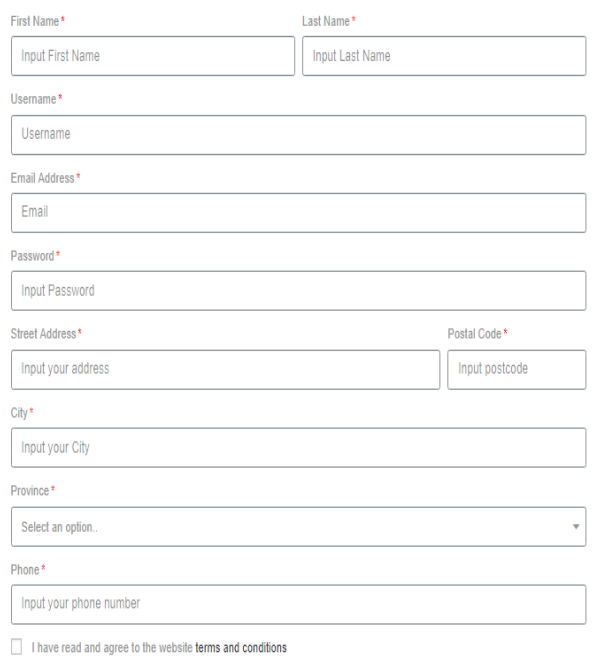

REGIST

Gambar 13. Proses Pendaftaran akun b. Cart

Form cart pada Gambar 14 adalah form dimana pelanggan melakukan proses menambahkan barang yang di pesan ke dalam keranjang belanja.
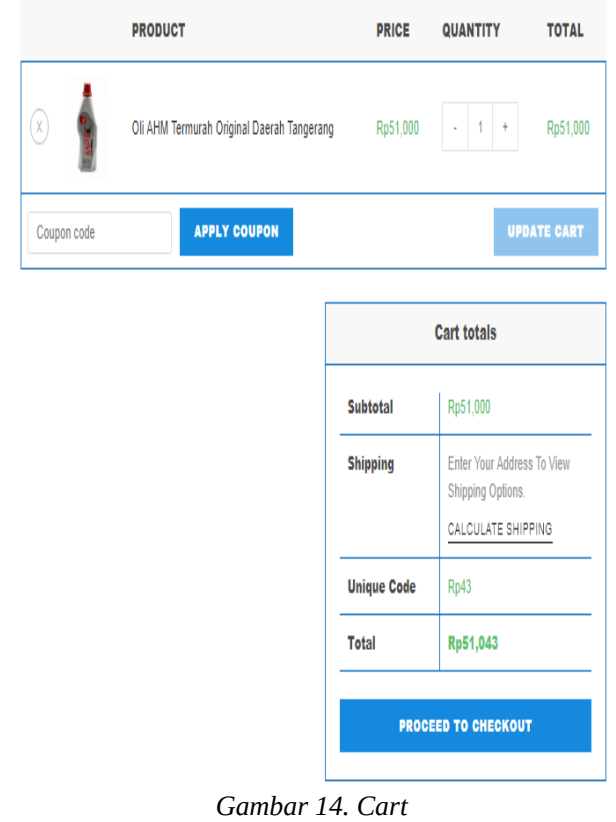

c. Checkout

Form checkout pada Gambar 15 adalah form dimana pelanggan melakukan pembayaran untuk barang yang telah di pesan.

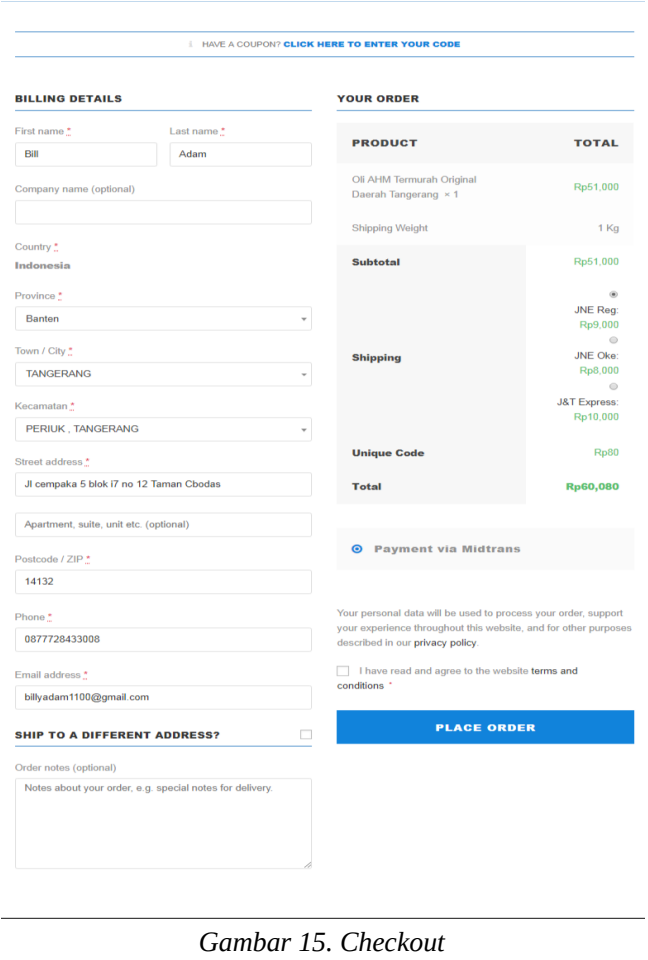




\section{d. Payment}

Form payment pada Gambar 16 adalah form yang digunakan oleh pelanggan untuk memilih metode pembayaran yang diinginkan.

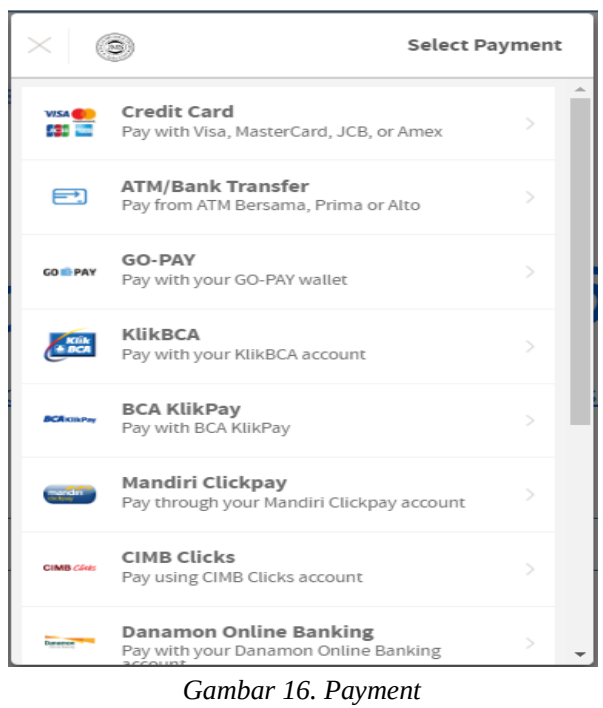

e. Laporan

Pada rancangan layar laporan pada Gambar 17 adalah form untuk menampilkan data hasil penjualan barang berdasarkan tanggal atau bulan atau periode tertentu.

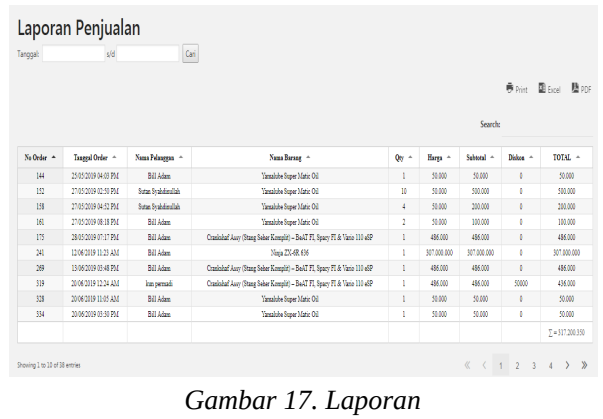

\section{KESIMPULAN}

Berdasarkan analisa dan penelitian yang sudah dilakukan pada Jogja Motor Sports maka dapat ditarik kesimpulan sebagai berikut :

a. Pelanggan dapat mengetahui sparepartsparepart yang sedang dijual promo dengan mengakses website

b. Penyajian data dan informasi sudah dapat dikelola dengan baik dengan menggunakan fitur checkout pada website yang akan berdampak pada kemudahan pelanggan melakukan transaksi jual-beli online.

c. Sistem sudah dapat membuat laporan yang dapat menyajikan informasi dalam periode waktu tertentu. d. Jogja Motor Sports sudah dapat memasarkan produknya secara global dengan membuat akun media sosial sehingga tidak menutup kemungkinan akan ada calon pelanggan yang berbelanja online.

\section{DAFTAR PUSTAKA}

[1] W. S. Dewobroto, "Penggunaan Business Model Canvas Sebagai Dasar Untuk Penggunaan Business Model Canvas Sebagai Dasar Untuk Menciptakan Alternatif Strategi Bisnis Dan,” J. Tek. Ind., no. November 2012, pp. 215-230, 2016.

[2] J. Tam and T. A. Model, "Sistem Informasi Penjualan Produk Berbasis Web Pada Chanel Distro Pringsewu,” J. TAM (Technology Accept. Model), vol. 4, pp. 1-7, 2015.

[3] M. M. S. R. S. Heru, "Implementasi E-commerce Sebagai Media Penjualan Online (Studi Kasus Pada Toko Pastbrik Kota Malang),” J. Adm. Bisnis, vol. 29, no. 1, pp. 1-9, 2015.

[4] T. A. Kurniawan, "PEMODELAN USE CASE (UML): EVALUASI TERHADAP BEBERAPA KESALAHAN DALAM PRAKTIK USE CASE (UML) MODELING : EVALUATION ON SOME PITFALLS IN PRACTICES,” vol. 5, no. 1, pp. 7786, 2018

[5] A. Saputra, "Sistem Informasi Manajemen Pendistribusian Barang Bekas Pada UD. Yuli Mutiara Dengan Bahasa Pemograman PHP Dan Database MySQL,” Sist. Inf. Manaj. Pendistribusian Barang Bek. Pada UD. Yuli Mutiara Dengan Bhs. Pemograman PHP Dan Database MySQL, vol. 25, no. 2, pp. 180-188, 2014.

[6] T. Wahyuningrum and D. Januarita, "Perancangan WEB e-Commerce dengan Metode Rapid Application Development (RAD) untuk Produk Unggulan Desa," vol. 2014, no. November, pp. 81-88, 2014 